\title{
The Mediation Effect of Moral Disengagement on Spiritual-Religious Attitudes and Academic Dishonesty among Guidance and Counseling Students
}

\author{
Endang Rifani ${ }^{1}$, Sugiyo Sugiyo ${ }^{2}$, Edy Purwanto ${ }^{2}$ \\ Universitas PGRI Semarang, Indonesia ${ }^{1}$ \\ Universitas Negeri Semarang, Indonesia ${ }^{2}$ \\ Qndangrifani0@gmail.com*
}

\section{Article Information:}

Received October 5, 2020

Revised November 5, 2020

Accepted November 25, 2020

Keywords: academic dishonesty; guidance and counseling; spiritual-religious; moral disengagement

\section{Abstract}

Academic dishonesty is a morality problem that is often found in every level of education. It becomes a concern among guidance and counseling practitioner in the educational context. Regarding previous studies, spiritual-religious attitudes and moral disengagement predict individuals' academic dishonesty. To complete the gap of those studies, the current study investigated the role of moral disengagement to mediate the relationship between spiritual-religious attitudes and academic dishonesty in university students. There were 292 participants from four universities in Semarang participated in this study. The authors used a cross-sectional study and utilized google form to collect the data. The authors conducted three analyses, regression-based path analysis, mediation analysis using bias-corrected and bootstrapping. The results showed that there was a direct relationship among all variables, but they're found no mediation effect on moral disengagement. These findings imply the importance of counseling services to preserve students' morality so they could avoid academic dishonesty.

\section{INTRODUCTION}

Academic dishonesty is a serious academic problem for many countries (Ghias, Lakho, Asim, Azam, \& Saeed, 2014; Hensley, Kirkpatrick, \& Burgoon, 2013; Jurdi, Hage, \& Chow, 2012; Ma, McCabe, \& Liu, 2013; Mwamwenda, 2012; Sattler, Graeff, \& Willen, 2013). McCabe and International Center of Academic Integrity have proved it in their study that between 2002 and 2015 of 71,300 undergraduate students, 39\% admitted cheating during exams, $62 \%$ admitted cheating on their report writing, while $68 \%$ did both. These findings clarify the deviations of six fundamental values of academic integrity proposed by The Center of Academic Integrity, including honesty, fairness, trust, respect, responsibility, and courage (Fishman, 2013). The deviation might not happen if students had integrity and honesty as obvious characters they must have. The phenomenon of academic dishonesty somehow shares a negative perception on the credibility of the national higher education system and may arise a trust issue towards it (Albatch, 2004). It manifests in the form of cheating, plagiarism, violating cooperation, breaking exams rules, and doing manipulation (Giluk \& Postlethwaite, 2015; McCabe, Trevino, \& Butterfield, 2001). Surely, it is affected by various factors.

Balbuena \& Lamela (2015) mention individuals experience an ethical value dilemma that they admit they cheat and know that cheating is an amoral action, but they keep doing it

How to cite:

E-ISSN:

Published by:
Rifani, E., Sugiyo, S., \& Purwanto, E. (2021). The Mediation Effect of Moral Disengagement on SpiritualReligious Attitudes and Academic Dishonesty among Guidance and Counseling Students. Islamic Guidance and Counseling Journal, 4(1). https://doi.org/10.25217/igcj.v4i1.1147 2614-1566

Institut Agama Islam Ma'arif NU (IAIMNU) Metro Lampung 
due to various reasons. In addition, they tend to blame their external situations and conditions. This situation indicates the existence of moral reasoning. Stephens (2017) defines moral reasoning as an effort done by individuals to determine the direction of their actions when facing particular situations. The individuals like to externalize guilty by shifting responsibility to mitigating circumstances.

Social cognitive theory by Bandura (1996) calls the above behavior as disengagement of internal control or moral disengagement. It is a condition where individuals can disengage themselves from the consequences of things they have done, but retain their moral standards (Feist \& Fiest, 2009). McCabe (1993) in his study states that responsibility transfer is a common mechanism done in academic dishonesty since he found more than $50 \%$ of students rationalize academic dishonesty by shifting responsibility to factors that are outside themselves, such as situational factors.

Morality is strongly related to spiritual-religious aspect. Individuals with good spiritualreligious aspect is automatically able to distinguish the good and bad of every action they perform. There is a mediation effect of moral disengagement on the relationship between religiosity and deviant behavior (Cardwell, 2018). He states that moral disengagement successfully contributes to indirect aspect among both variables. Cardwell then recommends to explore moral disengagement as a mediator variable of the relationship between spiritualreligious and other deviant behaviors. Additionally, Detert, Treviño, \& Sweitzer (2008) argue that moral disengagement can be a mediator between positive attitudes and deviant behavior. Therefore, purpose of this study was to investigate the role of moral disengagement in mediating the relationship between spiritual-religious and academic dishonesty.

Moral disengagement is a negative domain which leads individuals to behave immorally, in which one aspect that influences it is the spiritual-religious level (George \& Jefferson, 2014; Marquette, 2011). Religiosity affects moral disengagement, so individuals who understand and carry out religious activities faithfully obey the existing regulations which are related to moral values (D'Urso, Petruccelli, \& Pace, 2019). Even more, those who have high spiritual-religious values reflected in their actions will have less possibilities to behave amorally.

Previous studies found individuals who are likely to involve in religious activities have less possibilities to engage academic dishonesty (James, Talpade, \& Haynes, 2011). Equal to Rettinger \& Jordan (2005), the high religiosity of students brings them honest behavior in academy. It makes them follow moral principles based on religious beliefs, commit to their jobs and be cooperative in positive performance (Murtaza et al, 2016). The higher the individual's attachment to religious activities the stronger their attachment to comply with applicable academic ethics (de Soto, Tajalli, Pino, \& Smith, 2018).

Studies have found moral disengagement significantly predicts individuals' involvement in academic dishonesty (Farnese et al., 2011; Yang et al., 2010). For more, recent studies concerning academic dishonesty seen from the perspective of moral done by Ampuni, Kautsari, Maharani, Kuswardani, \& Buwono (2019) found that moral disengagement is the strongest predictor that affects academic dishonesty behavior. When individuals decide to engage academic dishonesty, they morally will disengage themselves to be freed from responsibility as a consequence.

The relationship between spiritual-religious attitudes, moral disengagement, and deviant behavior have been examined by Cardwell (2018). He found that moral disengagement is able to give mediating effects on the relationship between spiritual-religious attitudes and deviant behavior. He further recommends to conduct a study regarding spirituality, religiosity, moral disengagement, and other deviant behaviors, such as academic dishonesty. The current study realizes this idea. One reason of conducting this topic is the success of moral disengagement role in mediating positive attitudes and unethical behavior by some previous studies 
(Cardwell, 2018; Detert et al., 2008; Vincent, Emich, \& Goncalo, 2013). Individual involvement in academic dishonesty is included in unethical behavior (Stephens, 2019).

This research will find out the relationship between spiritual-religious and academic dishonesty through moral disengagement as a mediating variable. This is based on findings from Cardwell's (2018) research on the role of moral disengagement in mediating the relationship between spiritual-religious and deviant behavior, then he suggests further researching the role of moral disengagement in mediating the relationship between spiritualreligious and academic dishonesty in different populations.

\section{Rationale of the Current Study}

After conducting a survey related to academic integrity behavior, researchers found problems related to academic dishonesty, moral violations, and low student attachment to spiritual-religious attitudes. Then the researcher conducted a review on the results of previous studies related to academic dishonesty, and found factors from involvement in academic deviant behavior, it was found that moral and spiritual-religious factors could influence. So the focus of this research is to find the role of moral disengagement as a variable mediating the relationship between spiritual-religious and academic dishonesty. To do this, this research uses three research scales, namely the moral disengaged scale (Bandura, 1996), the centrality of religious scale (Huber \& Huber, 2012), and the academic dishonesty scale (Bashir \& Bala, 2018).

\section{Hypotheses}

1. Direct and significant relationship between spiritual-religious attitudes and moral disengagement (H1).

2. Direct and significant relationship between spiritual-religious attitudes and academic dishonesty $(\mathrm{H} 2)$.

3. Direct and significant relationship between moral disengagement and academic dishonesty (H3).

4. Indirect relationship between spiritual-religious attitudes and academic dishonesty through moral disengagement (H4).

\section{METHODS}

\section{Research Design}

This study used a quantitative approach and a survey method with a cross-sectional design. This study collaborated with the head of the guidance and counseling department at four universities. They were help authors to distribute the scale to guidance and counseling students as the participants.

\section{Participants}

This study involved 292 university students, consist of 179 female and 113 male, with an average age 20.6 years and studied in Guidance and Counseling major at 4 universities located in the city of Semarang, Central Java, Indonesia. The participants were invited by using simple random sampling technique.

\section{Instruments}

Three different scales were used in the data collection process. Prior to the distribution, the instrument has passed several adaptation stages, namely 1) forward translation, 2) translation review, decentering, and reconciliation of content, 3) back-translation, 4) commit or team review and further cultural adaptation, and 5) team review and consensus forming. 
First, the Moral Disengagement Scale (Bandura, 1996), consist of 32 items with 5 answer choices 1)strongly disagree, 2) disagree, 3) neutral, 4) agree, 5) strongly agree and showed a good reliability $(\alpha=.902)$. The scale used to measure the level of Moral Disengagement. The example of its statement item is "Sharing exam questions is just a way to help your friends", "Looking at a friend's homework without permission is just "browwing it", and "Not working very hard in school is really no big deal when you consider that other people are probably cheating".

The Second scale is Centrality of Religious Scale designed by Huber \& Huber (2012) to measure the level of spiritual-religious attitudes. The scale has 15 items with 5 answer choices 1) not at all, 2) not very much, 3) moderately, 4) quite a bit, 5) very much so, and showed a good reliability ( $\alpha=.956$ ) with the example of item "how often do you think about religion?", "How often do you experience situations in which you have the feeling that God or something divine intervenes in your life?", and "How important is to take part in religious services?".

The third scale used was academic dishonesty scale designed by Bashir and Bala (2018). This scale has 23 items with 5 answer choices 1) strongly agree, 2) agree, 3) neutral, 4) disagree, 5) strongly disagree, and showed a good reliability $(\alpha=.966)$. It was used to measure university students' honesty level by using a statement like "during the exam, I try to copy answers from other students", "I provide false excuses to teacher, to gain extra time on project/assignment", and "Before exam I pay someone to write a paper/homework for me". All three scales use likert scale from 1-5 answer choices.

Table 1. Demographical information of participants

\begin{tabular}{lll}
\hline Demographical factors & $\mathrm{N}(292)$ & Percentage $(\%)$ \\
\hline Gender & & \\
Female & 179 & $61.3 \%$ \\
Male & 113 & $38.7 \%$ \\
Age & & \\
$17-21$ & 198 & $67.9 \%$ \\
$22-27$ & 94 & $32.1 \%$ \\
Occupation status & & \\
Employed & 42 & $14.3 \%$ \\
Unemployed & 250 & $85.7 \%$ \\
College semester & & \\
$1-3$ & 93 & $31.8 \%$ \\
$5-9$ & 199 & $68.2 \%$ \\
\hline
\end{tabular}

Table 2. The Results of Path Analysis (a) of Spiritual-Religious Attitudes and Moral Disengagement

\begin{tabular}{lllllll}
\hline Outcome M & B & SE & T & P & LLCI & ULCI \\
\hline $\mathrm{X}(\mathrm{SR})$ & -.3513 & .1902 & -1.8467 & .0658 & -.7256 & .0231
\end{tabular}

Note: $\mathrm{SR}=$ Spiritual-Religius

Table 3. The Results of Path Analysis (b) of Moral Disengagement and Path (c) Spiritual Religious Attitudes and Academic Dishonesty

\begin{tabular}{lllllll}
\hline Outcome Y & B & SE & T & P & LLCI & ULCI \\
\hline X (SR) & -.3571 & .1100 & -3.2475 & .0013 & -.5735 & -.1407 \\
M (MD) & .5536 & .0337 & 16.4045 & .0000 & .4872 & .6201 \\
\hline
\end{tabular}

Notes: $\mathrm{M}=$ Moral Disengagement, $\mathrm{X}=$ Spiritual-Religious Attitudes

Table 4. The Indirect Relationship between Spiritual-Religious Attitudes and Academic Dishonesty Mediated by Moral Disengagement

\begin{tabular}{lllll}
\hline Outcome X on Y & $\beta$ & BootSE & BootLLCI & BootULCI \\
\hline $\mathrm{M}(\mathrm{MD})$ & -.1945 & .1066 & -.3931 & .0212 \\
\hline
\end{tabular}

Note: $\mathrm{M}=$ Moral Disengagement 


\section{Data Analysis}

Regression-based path-analytic framework was employed to determine the relationship among variables, namely dependent and independent variables, dependent and mediator variables, and mediator and dependent variables. Upon the determination of relationship, bias corrected, bootstrapping $\mathrm{N}=500$ with the confidential interval of $95 \%$ was performed to know the mediating or indirect effects between independent and dependent variables, namely the indirect effects of moral disengagement in mediating the relationship between spiritualreligious attitudes and academic dishonesty. Further data analysis was accomplished using SPSS 25.

\section{RESULTS AND DISCUSSION}

\section{Results}

There were 292 participants in this study, including 179 female students and 113 male students. In details, those whose age ranged from 17-21 years were 198 students, while the 22-27 years amounted to 94 students. Of 292 students, there were 42 students active as an employee, while the rest 250 were unemployed. Moreover, in terms of semester, the students who were in semester 1-3 were 93 people, and those who were in semester 5-9 were 199 people. The demographical data of participants illustrated in Table 1.

Path (a) presents the relationship between independent variable (spiritual-religious attitudes) and mediator variable (moral disengagement). It obtained the coefficient of $(\beta=-$ .3513 and significance at the level of $\mathrm{p}<.05$ ). These results implied that spiritual-religious attitudes and moral disengagement had a significant relationship. It was understood that according to the coefficient value, the relationship was negative, yet those variables had a direct relationship. Therefore, hypothesis (H1) is accepted.

Path (b) coefficient shows a direct relationship between variable $\mathrm{M}$ and $\mathrm{Y}$ in Table 2 with the coefficient value of $(\beta=.5536$ and significance $p<.05)$. These numbers proved no significant relationship between moral disengagement and academic dishonesty. It was because the coefficient value they had was positive, but still, there was a significant relationship between moral disengagement and academic dishonesty so that hypothesis $(\mathrm{H} 3)$ is accepted.

Path (c) coefficient which discussed the relationship between variable $\mathrm{X}$ and $\mathrm{Y}$ obtained the coefficient value of $(\beta=-.3571$ and significance of $p<.05)$. These results inferred that spiritual-religious attitudes and academic dishonesty had a direct and significant relationship. Thus, hypothesis (H2) is accepted. Additionally, regarding the value of $\beta=-.3571$, spiritualreligious attitudes had a negative relationship with academic dishonesty in which if students' spiritual-religious attitudes are high, their academic dishonesty will be low.

Table 3 presents the results of the test for mediator variable between spiritual-religious attitudes and academic dishonesty through moral disengagement. It obtained $\beta=-.1945$, while the confidence interval from bootstrapping resulted $(95 \%)-.3921$ and $=.0212$. Since zero is included in the $95 \%$ confidence interval, it can be concluded that there found no indirect effect on the relationship between spiritual-religious attitudes and academic dishonesty through moral disengagement, so that the hypothesis $(\mathrm{H} 4)$ is rejected.

The Figure 1. describing the results of data processing by 4 PROCESS template model (Hayes, 2013) and the relationship between variables appeared in path (a), path (b), path (c), and outcome Y.

\section{Discussion}

This study attempted to determine the role of moral disengagement in mediating the relationship between spiritual-religious attitudes and academic dishonesty. According to the data in path (a), spiritual-religious attitudes had a negative relationship with moral 
disengagement, meaning that students with high spiritual-religious had low moral disengagement, and vice versa. This finding is in line with a study by Nolan (2014) that individuals with high spiritual-religious attitudes significantly have a negative relationship with moral disengagement. By having this state, the individuals are able to regulate themselves to act properly as reflected in their behavior or in other words, they behave morally so that there is no chance for moral disengagement to occur.

Path (b) analysis which shows the relationship between moral disengagement and academic dishonesty revealed that moral disengagement significantly had a positive relationship with academic dishonesty, indicating that students with high moral disengagement would possibly have a high chance to involve in academic dishonesty. This is supported by a study of Farnese, Tramontano, Fida, \& Paciello (2011) which concludes that moral disengagement significantly predicts individuals' involvement in academic dishonesty. In this way, the findings of this study strengthen the fact that academic dishonesty deals with morality that in terms of moral disengagement, students will tend to disengage their responsibility for what they have done by blaming anything outside of themselves as the cause of involvement in academic dishonesty. The aforementioned explanation assures that individuals who are involved in academic dishonesty realize that what they have done contradicts to norms, but they keep doing it because of internal and external stimuli which in turn would make them feel discomfort, such as by saying "it was not only me who cheated during the exams. My friends did it, too."

Path (c) analysis confirmed that there was a relationship between spiritual-religious attitudes and academic dishonesty that according to the results, there found a direct and significant relationship between them. It is in accordance with a study by Khan et al. (2019) which found that spiritual-religious attitudes are predictors of students' academic dishonesty. If students have high spiritual-religious attitudes, they will avoid academic dishonesty, commit to their works, and be cooperative in their performance.

Table 4 showed that moral disengagement could not mediate the relationship between spiritual-religious attitudes and academic dishonesty. Apparently, these findings contradict to another study which states that moral disengagement is able to mediate the relationship of those variables (Cardwell, 2018; Detert et al., 2008; Vincent et al., 2013). There are several concepts which can answer the reason why moral disengagement cannot perform a mediated effect. First, Bandura (2002) does not consider moral disengagement as a belief system or value since individuals morally disengage it because of situational persuasion. Second, Nolan (2014) found that individuals with higher religious intellectuality own a high tendency to perform moral disengagement. Apart from the practical contribution, this study provides a novelty in guidance and counseling field since it investigated some recommendations suggested by previous researchers. First, this study involved guidance and counseling students

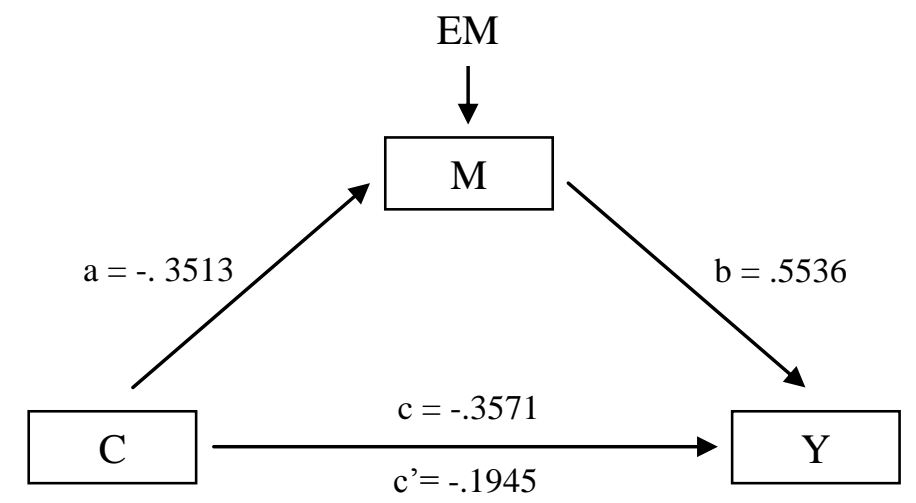

Figure 1. Data Processing Results and 4 PROCESS Template Model (Hayes, 2013) 
as suggested by Küçüktepe (2011) who researched guidance and counseling psychology students in Marmara University who experienced academic dishonesty. Second, the findings of this investigation were based on the perspective of counselors candidates. It is in line with the suggestion from McHaney, Cronan, \& Douglas (2016) who argue that one of the things that can play a role in addressing the problem of violations of academic integrity, particularly academic dishonesty is the provision of counseling services for students at risk. This theory is supported by American Counseling Association code of ethics (2014) stated that professional counselors do not commit plagiarism. Therefore, the involvement of counselors in counseling services are significant to academic problems in higher education.

Academic dishonesty, spiritual-religious attitudes, and moral disengagement are crucial issues, and this study reveals that students are still involved in academic dishonesty and commit moral disengagement. It is the counselor's realm to help individuals nurture development in social, learning, and personal contexts (Awalya et al., 2020). To overcome this, the provision of guidance and counseling services is expected to have a positive influence on student learning so that they can behave in accordance with the code of ethics applied at the university.

\section{Limitations and Suggestions}

Even though the researchers obtained some advantageous findings, this study is inseparable from limitations. First, it did not reveal the background of students' spiritualreligious attitudes so that the findings on this variable is general and not focused on diverse students' background. Second, this study is limited in respondents' involvement. As a result, the future studies are suggested to involve more respondents and further investigate the relationship between spiritual-religious attitudes, moral disengagement, and academic dishonesty, especially the role of moral disengagement as a mediator variable. Also, there is a need to add other variables which support this exploration.

\section{Implications}

This research has implications for guidance and counseling, especially in counseling services in universities. The data from this study came from student respondents with guidance and counseling. Considering the impact of the dishonesty academy case, which is a matter of morality, it implies that it is important to provide counseling services in higher education as a means for the welfare of students in relation to daily effective life and morality. Naser (2019) states that the role of the counselor in strengthening moral values can be done by integrating religiosity in the implementation of guidance and counseling itself. Another important thing is that integrating spiritual-religious values in counseling helps the counselee feel more accepted.

The main duties and functions of guidance and counseling services cover aspects of the chair which are able to provide effective daily life, including in the spiritual-religious realm. Supriyanto (2016) found that guidance and counseling have a role to facilitate students in the process of increasing spiritual-religious competence. Added by Rianita, Trisnawati, \& Nopiyani (2020) found that providing guidance and counseling services with spiritual motivation can increase motivation and learning outcomes in students.

\section{CONCLUSIONS}

This study analyzed the relationship between spiritual-religious attitudes and academic dishonesty through the role of moral disengagement as a mediator variable on Guidance and Counseling department students in the city of Semarang, Central Java, Indonesia. It confirms a significant relationship between spiritual-religious attitudes and academic dishonesty without a mediator variable, high moral disengagement is in line with high academic 
dishonesty, and significant relationship between spiritual-religious attitudes and moral disengagement. Within these results, the researchers found that moral disengagement cannot mediate the relationship between spiritual-religious attitudes and academic dishonesty. However, all those three variables have a significant relationship. At last, the limitations of this study lie on the absence of a control variable which can neutralize data, so the future studies are recommended to add a control variable in the process of analysis, such as the variable of age or gender.

\section{ACKNOWLEDGEMENTS}

The author expresses their sincere thanks to Mulawarman, Ph.D, Sunawan, Ph.D, and Dr. Awalya for the supervision of study. Dr. Edy Purwanto from Universitas Negeri Semarang, Ema Hidayanti from UIN Walisongo, Heri Saptadi S.Pd., M.Pd., Kons from Universitas PGRI Semarang, and Elfi Rimayati, M.Pd from Universitas IVET Semarang.

\section{AUTHOR CONTRIBUTIONS STATEMENT}

ER designs study implementation data collection, and interventions at the study location. SG and EP provide direction as well as assisting in the preparation of study designs and supervision during the study conducted.

\section{REFERENCES}

Albatch, P. G. (2004). The Question of 'Corruption' in Nepal. Mankind, 34(1), 7-8. https://doi.org/10.1111/j.1835-9310.1987.tb00738.x

American Counseling Association (2014). ACA code of ethics. Alexandria, VA: Author. Google Scholar

American Psychological Association. (2015). American Psychological Association ethical principles of psychologists and code of conduct. Google Scholar

Ampuni, S., Kautsari, N., Maharani, M., Kuswardani, S., \& Buwono, S. B. S. (2019). Academic Dishonesty in Indonesian College Students: an Investigation from a Moral Psychology Perspective. Journal of Academic Ethics. https://doi.org/10.1007/s10805019-09352-2

Awalya, A., Nugraha, Y. P., Syifa, L., \& Rifani, E. (2020). Aplikasi kompetensi konselor sekolah. Semarang: Fasindo. Google Scholar

Balbuena, S. E., \& Lamela, R. A. (2015). Prevalence, Motives, and Views of Academic Dishonesty in Higher Education. 3(2). Google Scholar

Bandura, A., Barbaranelli, C., Caprara, G. V., \& Pastorelli, C. (1996). Mechanisms of moral disengagement in the exercise of moral agency. Journal of Personality and Social Psychology, 71(2), 364-374. https://doi.org/10.1037/0022-3514.71.2.364

Bandura. (2002). Selective moral disengagement in the exercise of moral agency. Journal of Moral Education, 31(2), 101-119. https://doi.org/10.1080/0305724022014322

Bandura. (2016). Moral disengagement: How people do harm and live with themselves. New York: Worth Publishers. Google Scholar

Bashir, H., \& Bala, R.(2018). Development and Validation of Academic Dishonesty Scale (ADS): Presenting a Multidimensional Scale. International Journal of Instruction, 11(2), 57-74. https://doi.org/10.12973/iji.2018.1125a

Cardwell, S. M. (2018). The longitudinal relations between religiosity, moral disengagement, and offending in serious adolescent ofenders. Dissertation Abstracts International Section A: Humanities and Social Sciences, 79. Google Scholar

D’Urso, G., Petruccelli, I., \& Pace, U. (2019). Attachment style, attachment to God, religiosity, and moral disengagement: a study on offenders. Mental Health, Religion and Culture, 22(1), 1-11. https://doi.org/10.1080/13674676.2018.1562429 
de Soto, W., Tajalli, H., Pino, N. W., \& Smith, C. L. (2018). The effect of college students' religious involvement on their academic ethic. Religion and Education, 45(2), 190-207. https://doi.org/10.1080/15507394.2018.1425077

Detert, J. R., Treviño, L. K., \& Sweitzer, V. L. (2008). Moral Disengagement in Ethical Decision Making: A Study of Antecedents and Outcomes. Journal of Applied Psychology, 93(2), 374-391. https://doi.org/10.1037/0021-9010.93.2.374

Farnese, M. L., Tramontano, C., Fida, R., \& Paciello, M. (2011). Cheating behaviors in academic context: Does academic moral disengagement matter? Procedia - Social and Behavioral Sciences, 29, 356-365. https://doi.org/10.1016/j.sbspro.2011.11.250

Feist, J., \& Feist, G. J. (2009). Theories of personality. Boston, MA: McGraw Hill Higher Education. Google Scholar

Fishman, T. (2013). International Centre for Academic Integrity. In The fundamental values of Academic integrity (Vol. 2). https://doi.org/10.15713/ins.mmj.3

George, R., \& Jefferson. (2014). Moral Disengagement: An Exploratory Study of Predictive Factors for Digital Aggression and Cyberbullying. Doctor of PhilosophyEducational Leadership, 144, 24-90. Google Scholar

Ghias, K., Lakho, G. R., Asim, H., Azam, I. S., \& Saeed, S. A. (2014). Self-reported attitudes and behaviours of medical students in Pakistan regarding academic misconduct: A cross-sectional study. BMC Medical Ethics, 15(1). https://doi.org/10.1186/1472-6939$15-43$

Giluk, T. L., \& Postlethwaite, B. E. (2015). Big Five personality and academic dishonesty: A meta-analytic review. Personality and Individual Differences, 72, 59-67. https://doi.org/10.1016/j.paid.2014.08.027

Hayes, A. F. (2013). Methodology in the social sciences.Introduction to mediation, moderation, and conditional process analysis: A regression-based approach. Guilford Press. Google Scholar

Hensley, L. C., Kirkpatrick, K. M., \& Burgoon, J. M. (2013). Relation of gender, course enrollment, and grades to distinct forms of academic dishonesty. Teaching in Higher Education, 18(8), 895-907. https://doi.org/10.1080/13562517.2013.827641

Huber, S., \& Huber, O. W. (2012). The Centrality of Religiosity Scale (CRS). Religions, 3(3), 710-724. https://doi.org/10.3390/rel3030710

James, B., Talpade, S., \& Haynes, J. (2011). Religiosity and Test-Taking Ethics among Business School Students. Journal of Academic and Business Ethics, 4, 1-8. . http://www.aabri.com/manuscripts/11759.pdf

Jurdi, R., Hage, H. S., \& Chow, H. P. H. (2012). What behaviours do students consider academically dishonest? Findings from a survey of Canadian undergraduate students. Social Psychology of Education, 15(1), 1-23. https://doi.org/10.1007/s11218-011-9166$\mathrm{y}$

Khan, I. U., Khalid, A., Hasnain, S. A., Ullah, S., Ali, N., \& Zealand, N. (2019). The Impact of Religiosity and Spirituality on Academic Dishonesty of Students in Pakistan. European Online Journal of Natural and Social Sciences, 8(3), 381-398. Retrieved from http://european-science.com/eojnss/article/view/5525

Küçüktepe, S. E. (2011). Evaluation of tendency towards academic dishonesty levels of psychological counseling and guidance undergraduate students. Procedia - Social and Behavioral Sciences, 15, 2722-2727. https://doi.org/10.1016/j.sbspro.2011.04.177

Ma, Y., McCabe, D. L., \& Liu, R. (2013). Students' Academic Cheating in Chinese Universities: Prevalence, Influencing Factors, and Proposed Action. Journal of Academic Ethics, 11(3), 169-184. https://doi.org/10.1007/s10805-013-9186-7

Marquette, H. (2011). "Finding God" or "moral disengagemnt" in the fight against corruption in developing countries? Evidence from india and nigeria. Public Administration and 
Development, 10, 1-10. https://doi.org/10.1002/pad

McCabe, D. L., Trevino, L. K., \& Butterfield, K. D. (2001). Dishonesty in academic environments: The influence of peer reporting requirements. Journal of Higher Education, 72(1), 29-45. https://doi.org/10.1080/00221546.2001.11778863

McHaney, R., Cronan, T. P., \& Douglas, D. E. (2016). Academic Integrity: Information Systems Education Perspective. Journal of Information Systems Education, 27(3), 153 158. Google Scholar

Murtaza, G., Abbas, M., Raja, U., Roques, O., Khalid, A., \& Mushtaq, R. (2016). Impact of Islamic work ethics on organizational citizenship behaviors and knowledge-sharing behaviors. Journal of Business Ethics, 133(2), 325-333. https://doi.org/10.1007/s10551014-2396-0

Mwamwenda, T. S. (2012). Maintaining academic integrity among East African university students. Africa Education Review, 9(3), 452-465. https://doi.org/10.1080/18146627.2012.742670

Naser, N. (2019). Konselor dalam penguatan nilai dan moral: strategi membentuk generasi religius. Jurnal Ilmiah Syi'ar, 19(1), 30-42. Google Scholar

Nolan, C. (2014). Good without god?- the influence of religion on altruistic acts and moral disengagement. Google Scholar

Rettinger, D. A., \& Jordan, A. E. (2005). The relations among religion, motivation, and college cheating: A natural experiment. Ethics and Behavior, 15(2), 107-129. https://doi.org/10.1207/s15327019eb1502_2

Rianita, N. M., Trisnawati, N. L. D E., \& Nopiyani, P. E. (2020). Peningkatan motivasi belaar berbasis spiritual terhadap hasil belajar mahasiswa. Mimbar Ilmu, 25 (3), 338-345. https://e.journal.undiksha.ac.id/index.php/MI/article/view/28312

Sattler, S., Graeff, P., \& Willen, S. (2013). Explaining the Decision to Plagiarize: An Empirical Test of the Interplay Between Rationality, Norms, and Opportunity. Deviant Behavior, 34(6), 444-463. https://doi.org/10.1080/01639625.2012.735909

Stephens, J. M. (2017). How to Cheat and Not Feel Guilty: Cognitive Dissonance and its Amelioration in the Domain of Academic Dishonesty. Theory into Practice, 56(2), 111120. https://doi.org/10.1080/00405841.2017.1283571

Stephens, J. M. (2019). Natural and Normal, but Unethical and Evitable: The Epidemic of Academic Dishonesty and How We End It. Change: The Magazine of Higher Learning, 51(4), 8-17. https://doi.org/10.1080/00091383.2019.1618140

Supriyanto, S. (2016). Colaboration counselor and parent for developing students spirtual competency through comprehensive guidance and counseling service. Journal Fokus Counseling, 2(1), https://doi.org/10.26638/jfk.131.2099

Vincent, L. C., Emich, K. J., \& Goncalo, J. A. (2013). Stretching the Moral Gray Zone: Positive Affect, Moral Disengagement, and Dishonesty. Psychological Science, 24(4), 595-599. https://doi.org/10.1177/0956797612458806

Yang, Ji-ping., Wang, Xing-chao., Lu, Li-jun., \& Zhang, Li-wei. (2010). The relationship between moral disengagement and academic dishonesty behavior of college students. Psychological Development and Education, 26(4): 364-370. http://www.devpsy.com.cn/EN/Y2010/V26/I4/364 